\title{
Analisis Kelayakan Usaha Produksi Tahu Sumedang (Studi Kasus Di Pabrik Tahu XY Kecamatan Conggeang)
}

\section{Feasibility Analysis Sumedang Tofu Production Business (Case Study in XY Tofu Factory of Conggeang Sub-district)}

\author{
Nur Ali Sa'id ${ }^{1}$, Amar Ma'ruf ${ }^{1}$, Delfitriani Delfitriani ${ }^{1 \mathrm{a}}$ \\ 1Program Studi Teknologi Industri Pertanian, Fakultas Ilmu Pangan Halal Universitas Djuanda Bogor, \\ Jl. Tol Ciawi No. 1, Kotak Pos 35 Ciawi, Bogor 16720 \\ aKorespondensi : Delfitriani, E-mail: delfitri70@gmail.com
}

(Diterima oleh Dewan Redaksi : 15 - 03 - 2020)

(Dipublikasikan oleh Dewan Redaksi : 08 - 04 - 2020)

\begin{abstract}
Feasibility analysis of XY tofu production business is a factory that produces traditional food typical of the Sumedang district. This production utilizes the marketing sector and marketing location which is located near the sub-district traditional market. This study aims to analyze the business of tofu Sumedang in the XY tofu factory which includes non-financial aspects (Market aspects, marketing, engineering, management, legal, social and environmental), and financial aspects. Based on non-financial results hat the non-financial aspects affect the operation of the tofu XY production business. Based on the results of the calculation of financial aspects it is feasible to carry out the NVP value generated for 10 years Rp. 579,177,261 -, with production capacity per month producing tofu 216.000 seed and $6.806 \mathrm{~kg}$ tofu dregs per month. The IRR obtained is $0,41 \%$ where the IRR is more than $0 \%$. Net B / C obtained is 2,92 , this means, every Rp. 1 spent on running this business will generate net benefits of Rp.2,92. The payback period obtained is 2,63 years. The sensitivity analysis for this project shown an increase in operational / production costs of $10 \%$, an increase in raw materials and additional materials by $20 \%$ and a decrease in selling prices by $10 \%$ which does not affect this business.
\end{abstract}

Keywords: feasibility business, financial analysis, sensitivity analysis

\begin{abstract}
ABSTRAK
Analisis kelayakan usaha tahu XY adalah pabrik yang memproduksi makanan tradisional khas daerah kabupaten Sumedang. Produksi ini memanfaatkan sektor pemasaran dan lokasi pemasaran yang bertempat didekat pasar kecamatan. Penelitian ini bertujuan untuk menganalisis kelayakan usaha tahu sumedang di pabrik tahu XY yang meliputi aspek non finansial (aspek pasar, aspek pemasaran, aspek tenik, aspek manajemen, aspek hukum, aspek sosial dan aspek lingkungan) dan aspek finansial. Berdasarkan hasil non Finansial, bahwa aspek-aspek non finansial berpengaruh terhadap bejalannya usaha produksi tahu XY. Berdasarkan hasil perhitungan aspek finansial layak untuk dilaksanakan dengan nilai NVP yang dihasilkan selama 10 tahun Rp. 579.177.261-, dengan kapasitas produksi per bulan menghasilkan tahu 216.000 biji, dan ampas tahu 6.806 per bulan. Nilai IRR yang diperoleh yaitu 0,41\% dimana IRR lebih besar dari $0 \%$. Net B/C yang diperoleh yaitu 2,92, ini berarti, setiap $\mathrm{Rp} 1$ biaya yang dikeluarkan untuk menjalankan usaha ini akan mnghasilkan manfaat bersih sebesar Rp. 2,92. Payback Period yang diperoleh yaitu 2,63 tahun. Analisis sensitivitas untuk proyek ini menunjukkan kenaikkan biaya operasional/produksi sebesar 15\%, kenaikkan bahan baku dan bahan tambahan sebesar $20 \%$ tidak berpengaruh terhadap usaha ini. Pada analisis sensitifitas penurunan harga jual sebesar $10 \%$, berpengaruh terhadap produksi tahu, karena memiliki nilai negatif.
\end{abstract}

Kata kunci: analisis kelayakan produksi, analisis finansial, analisis sensitivitas

Sa'id, Nur Ali, Amar Ma'ruf, Delfitriani Delfitriani. 2019. Analisis Kelayakan Usaha Produksi Tahu Sumedang (Studi Kasus Di Pabrik Tahu XY Kecamatan Conggeang). Jurnal Agroindustri Halal 6(1): 105 $-113$. 


\section{PENDAHULUAN}

Tahu merupakan produk hasil olahan kedelai yang merupakan bahan baku hasil pertanian. Kabupaten Sumedang merupakan kota yang terkenal dengan produksi Tahu Sumedang. Tahu sumedang terkenal karena memiliki tekstur yang khas, yaitu warna putih saat tahu masih mentah dan memiliki bentuk fisik yang khas setelah digoreng yaitu kulit yang garing berwarna kuning keemasan atau coklat namun isinya masih lunak. Usaha pembuatan tahu merupakan usaha pokok bagi sebagian masyarakat Kabupaten Sumedang karena mempunyai nilai ekonomis yang tinggi dalam menyuplai kebutuhan pangan terutama protein nabati (Hapsari et al. 2016).

Penelitian ini memfokuskan pada pengembangan usaha tahu, dimana dalam pengembangan usaha sering mengalami risiko seperti kenaikan harga bahan baku, biaya operasional dan penurunan harga jual produksi. Risiko suatu usaha berbanding lurus dengan besarnya usaha tahu tersebut. Semakin besar suatu usaha dijalankan maka semakin besar pula risiko yang akan timbul, sehingga harus ada pengelolaan usaha yang tepat khususnya dari aspek finansial (keuangan) (Dewi 2016). Salah satu pabrik tahu yang telah dikenal di Kabupaten Sumedang yaitu Tahu XY. Pabrik tahu XY berdiri sejak tahun 1980, terletak di Kecamatan Conggeang Kabupaten Sumedang. Pabrik tahu ini memberikan sumbangsih dengan menyediakan lapangan pekerjaan untuk masyarakat kabupaten Sumedang.

Studi kelayakan usaha adalah penelitian dan penilaian tentang dapat atau tidaknya suatu proyek dilakukan dengan berhasil (menguntungkan). Menilai suatu penilaian, terlebih dahulu harus melakukan penilaian terhadap investasi yang akan digunakan, kemudian dituangkan dalam suatu laporan secara tertulis, laporan hasil studi kelayakan ini bisa digunakan sebagai pedoman/alat untuk mengetahui sampai sejauh mana kegiatan investasi telah dilakukan. Studi kelayakan dapat diukur berdasarkan aspek finansial dan non finansial. Aspek finansial dapat dinilai dari analisis kriteria investasi, karena sangat diperlukan untuk melihat perkembangan usaha kedepannya, sedangkan aspek non finansial dilakukan untuk mengukur keberadaan usaha dari segi sosial dan lingkungan (Maharani 2017).

Semua data, fakta dan berbagai pendapat yang ditemukan dalam studi kelayakan tersebut dapat menjadi dasar dalam pengambilan keputusan kelayakan pendirian pabrik Tahu $X Y$ selain itu, konsistensi dan keberadaan Tahu XY yang telah berlangsung selama 38 tahun mendorong penulis untuk melakukan analisis kelayakan usaha tersebut. Studi kelayakan ini mengkaji beberapa aspek yang berpengaruh terhadap kelayakan suatu industri tahu yaitu Tahu XY.

Penelitian sebelumnya yang menjadi acuan penelitian ini yaitu penelitian oleh Kurniawan (2016) mengenai kelayakan usaha tahu gemilang menggunakan analisis finansial dan non finansial, serta penelitian dari Simanjuntak (2017) tentang analisis kelayakan finansial pada perusahaan tahu di desa rancagong dengan metode finansial. Berdasarkan penelitian terdahulu tersebut maka penelitian ini bertujuan untuk menganalisis kelayakan usaha tahu sumedang di pabrik tahu XY yang meliputi aspek non finansial (aspek pasar, aspek pemasaran, aspek tenik, aspek manajemen, aspek hukum, aspek sosial dan aspek lingkungan) dan aspek finansial.

\section{MATERI DAN METODE}

\section{Pengumpulan Data}

Data yang digunakan pada penelitian ini adalah data primer dan sekunder. Data primer diperoleh dari hasil wawancara dan observasi langsung di tempat penelitian dengan pemilik Pabrik Tahu XY, pembuat tahu dan staf pemasaran dan penduduk sekitar pabrik tahu XY yang terkait dengan keperluan kajian aspek kelayakan usaha. Penentuan sampel responden untuk aspek kelayakan usaha dilakukan dengan metode sampling yaitu orang-orang yang memiliki informasi sempurna untuk menganalisis aspek kelayakan usaha, diantaranya adalah 
Kepala Desa Conggeang Kulon, tokoh masyarakat, Ketua RW, Sekretaris Camat, dua orang warga sekitar baik yang bekerja di Pabrik Tahu XY maupun tidak.

Data sekunder diperoleh dari instansiinstansi yang terkait dengan penelitian ini, yaitu Badan Pusat Statistik, Dinas Industri dan Perdagangan Kabupaten Sumedang., Kantor Desa Conggeang Kulon serta artikel elektronik yang terkait dengan penelitian ini. Informasi tambahan yang mendukung penelitian ini menggunakan literaturliteratur yang relevan dengan objek permasalahan.

\section{Analisi Data}

Data dan informasi yang diperoleh diolah dengan menggunakan kuesioner dan Microsoft Excel. Analisis data dilakukan secara kualitatif dan kuantitatif meliputi tahap pengolahan data dan interpretasi data secara deskriptif. Analisis kualitatif digunakan untuk mengetahui keragaan unit usaha produksi tahu XY di lokasi penelitian pada kondisi saat ini, seperti investasi, biaya pengeluaran dan pemasukan dan produk mulai dari masuk sampai pemasaran yang dihasilkan oleh pabrik tahu XY. Analisis kelayakan usaha dibagi menjadi analisis kelayakan non finansial dan analisis kelayakan finansial. Analisis kelayakan non finansial mengkaji berbagai aspek mulai dari aspek pasar, teknis, manajemen, hukum, sosial-ekonomi-budaya dan lingkungan. Analisis kuantitatif dilakukan untuk mengkaji kelayakan usaha produksi tahu secara finansial. Metode yang digunakan dalam analisis kuantitatif adalah analisis kelayakan finansial, analisis laba rugi dan analisis sensitivitas.

Pada penelitian ini, kriteria analisis kelayakan finansial yang digunakan yaitu Net Present Value (NPV), Net Benefit Cost Ratio (Net B/C), Internal Rate of Return (IRR), dan Payback Period. Analisis laba rugi digunakan perusahaan untuk mengetahui perkembangan usaha dalam periode tertentu dan akan mempermudah penentuan besarnya aliran kas tahunan yang diperoleh suatu perusahaan. Komponen variabel yang termasuk dalam laba rugi terdiri dari pendapatan pokok dan sampingan perusahaan, biaya operasional perusahaan dimana di dalamnya termasuk biaya penyusutan dari barang invetasi yang ditanamkan, beban bunga (jika perusahaan melakukan pinjaman).

Menghadapi kondisi ekonomi yang tidak menentu dalam setiap usaha diperlukan persiapan, apabila terjadi guncangan ekonomi yang menyebabkan adanya kenaikan biaya produksi atau kenaikan harga bahan baku, kenaikan biaya tenaga kerja dan penurunan penjualan, maka dilakukan analisis sensitivitas untuk mengetahui sejauh mana dapat bertahan dalam kondisi krisis dan ketidakpastian. Ketidakpastian dapat menyebabkan berkurangnya kemampuan dari suatu usaha dalam beroperasi menghasilkan laba (Syarif 2014).

\section{HASIL DAN PEMBAHASAN}

\section{Gambaran Umum Tahu Sumedang (Tahu $\mathrm{XY}$ )}

Usaha tahu Sumedang yang menjadi objek penelitian terletak di Desa Conggeang Kulon, Kecamatan Conggeang Kabupaten Sumedang. Tahu XY merupakan salah satu pabrik tahu yang terkenal di Kabupaten Sumedang dengan kapasitas produksi per hari 2 kwintal kedelai sebagai bahan baku pembuatan tahu.

Pada awal pendirian usaha ini hanya mempekerjakan 2 orang pekerja (1 orang pembuat tahu dan 1 orang penggoreng/penjual tahu) dan pabrik dengan ukuran $30 \mathrm{~m}^{2}$ dengan skala produksi per hari $50 \mathrm{~kg}$ kedelai. Usaha ini terus mengalami perkembangan pada tahun 2000 dengan memperluas wilayah pabrik menjadi $112 \mathrm{~m}^{2}$ dan mempekerjakan 4 orang pekerja. Hingga sekarang usaha tersebut telah mempekerjakan 8 orang pekerja.

\section{Analisis Kelayakan Non Finansial}

Aspek Pasar dan Pemasaran

Pada aspek pasar terdapat beberapa variabel yang dianalisis menurut Husnan dan Suwarsono (2016) meliputi: jumlah permintaan dan penjualan yang tercover 
dalam peluang usaha serta kajian pada bauran pemasaran. Berdasarkan hasil wawancara dan observasi dilapangan, tahu dipasarkan dalam bentuk tahu goreng. Sebagian konsumen membeli tahu untuk dijual kembali atau menjadi bahan tambahan dagangannya. Selain konsumen lokal konsumen juga berasal dari luar daerah yang membeli tahu sebagai buah tangan khas Sumedang. Selain tahu, dihasilkan juga produk sisa produksi berupa ampas tahu yang biasa dibeli oleh peternak sebagai pakan ternak.

Patokan harga tahu ditetapkan mengikuti harga kedelai. Harga tahu perbiji yaitu Rp.500,00 dan harga ampas tahu Rp.1000,00/kg. Saluran distribusi penjualan, yaitu pembeli datang langsung ke kios penjualan. Tidak ada perantara dalam pendistribusian tahu dan ampas tahu.

Promosi dapat dilakukan secara langsung dan tidak langsung. Promosi secara langsung seperti promosi yang secara sengaja dilakukan oleh perusahaan sedangkan promosi tidak langsung dilakukan melalui perantara. Hingga saat ini, usaha tahu XY tidak melakukan promosi secara langsung seperti menggunakan media Televisi, radio ataupun media lainnya. Promosi secara tidak langsung dilakukan melalui informasi secara perorangan.

\section{Aspek Teknis}

Kelayakan unit usaha produksi Tahu XY dari aspek teknis dapat dilihat dari teknis lokasi, teknis usaha produksi, luas produksi, layout, serta teknis pemilihan teknologi dan peralatan yang diterapkan. Jika dilihat dari teknis lokasi, unit usaha produksi tahu Sumedang layak untuk dijalankan karena berada di lingkungan pasar Kecamatan Conggeang, berada di pinggir jalan raya utama, tidak jauh dari pemukiman penduduk, terjaminnya input yang dibutuhkan, adanya letak pasar yang dituju, adanya tenaga listrik dan air yang dibutuhkan untuk kegiatan operasional usaha produksi tahu, adanya pasokan tenaga kerja dan fasilitas yang memadai serta adanya dukungan dari pemerintah dan instansi terkait yang membantu kelancaran kegiatan operasional unit usaha produksi tahu Sumedang XY.

Pembuatan tahu membutuhkan bahan baku utama berupa kacang kedelai. Dalam memproduksi tahu, pabrik XY menggunakan kacang kedelai impor lebih berkualitas, harganya cenderung lebih murah, dan kadar susunya lebih banyak dibandingkan dengan kacang kedelai lokal.

Pemenuhan kebutuhan bahan baku diperoleh dengan cara membeli kacang kedelai dari pasar Sumedang dengan harga rata-rata per ton. Pembelian kacang kedelai dilakukan setiap 2 minggu sekali, setiap pembelian kacang kedelai yaitu sebesar 4 ton kacang kedelai. Jadi dalam satu bulan, pabrik XY memenuhi kebutuhan kacang kedelai sebesar 8 ton.

Bahan baku dijadikan salah satu perhatian utama yang dipertimbangkan karena jika terjadi kekurangan akan mempengaruhi proses produksi. Proses dan teknologi yang digunakan dalam produksi berdasarkan atas kemudahan proses dan biaya produksi. Hal ini disebabkan, proses dan teknologi juga dijadikan dasar dalam pemilihan alat dan mesin produksi (Mansyur et al. 2015).

Tanah seluas $112 \mathrm{~m}^{2}$ yang dimiliki, dimanfaatkan untuk bangunan pabrik tahu, termasuk didalamnya adalah garasi, tempat produksi dan tempat penjualan dapat dilihat pada lampiran 6. Jika dilihat dari luas produksi, usaha produksi ini layak untuk dijalankan. Selain itu, jika dilihat dari layout lahan produksi, unit usaha tahu XY layak untuk dijalankan karena dengan konstruksi pabrik yang ada selama ini mampu menjamin keselamatan karyawan di dalamnya. Pada unit usaha produksi tahu XY, teknologi dan peralatan yang digunakan mampu menunjang usaha produksi sehingga dengan peralatan yang ada selama ini, unit usaha produksi tahu XY layak untuk dijalankan. Dapat disimpulkan bahwa jika dilihat dari aspek teknis secara keseluruhan, unit usaha produksi Tahu Sumedang XY layak untuk dijalankan. 
Aspek Manajemen

Badan usaha adalah kumpulan orang dan modal yang mempunyai kegiatan atau aktivitas yang bergerak dibidang perdagangan atau dunia usaha. Iskandar et al. (2015) menambahkan bahwa stuktur manajemen antar perusahaan ada kemungkinan terdapat perbedaan. Hal ini disesuaikan dengan skala usaha, strategi perusahaan serta keadaan karyawan perusahaan yang bersangkutan.Unit usaha produksi tahu XY adalah sebuah pengembangan usaha berupa integrasi vertikal dari usaha sebelumnya yang hanya memproduksi sebagian kecil. Sejak awal pendirian, belum adanya penyelesaian izin usaha yang dilakukan untuk mendapatkan bentuk badan usaha yang sah dari pemerintah pusat.

Bentuk badan usaha adalah nama yang melekat pada satu perusahaan sementara untuk skala usaha adalah nama yang melekat untuk tiap unit bisnis. Maka jika dilihat dari badan usaha, pabrik tahu XY berbadan usaha perorangan dan dari skala usahanya, unit usaha produksi tahu Sumedang berada pada skala usaha wajib izin karena jumlah pendapatan telah diusahakan berjumlah lebih dari Rp.1.000.000.000,00/ Tahun (Dinas Perindustrian Kabupaten Sumedang, 2014).

Aspek Hukum

Analisis pada aspek hukum terdiri dari bentuk usaha yang akan digunakan, jaminanjaminan yang dapat diberikan apabila hendak meminjam dana, akta, sertifikat dan izin yang diperlukan dalam menjalankan usaha (Bakhtiar et al. 2018). Unit usaha produksi tahu Sumedang adalah pabrik Tahu XY yang telah dijalankan sejak tahun 1983. Semakin bertambahnya kapasitas produksi, hingga saat ini perizinan yang telah dilakukan oleh $\mathrm{XY}$ hanya sebatas perizinan lokasi usaha produksi. Perizinan yang seharusnya diakukan adalah perizinan lokasi usaha dan perizinan usaha produksi. Perizinan lokasi yang telah didapatkan oleh XY, dilakukan melalui proses birokrasi yang panjang.

Berbagai tahapan harus dilakukan oleh pemilik seperti membuat Surat Keterangan
Domisili Usaha (SKDU) di tingkat Kecamatan Conggeang. Setelah ada penyataan dari kecamatan, surat keterangan tersebut digunakan sebagai bukti dalam pembuatan ijin prinsip di Dinas Perindustrian Kabupaten Sumedang. Setelah bukti izin prinsip itu keluar, maka perizinan dilanjutkan ke instansi selajutnya, yaitu Departemen Perdagangan untuk mendapatkan bukti Tanda Daftar Produksi (TDP).

Bersamaan dengan itu, pemilik juga melakukan perizinan ke Dinas Perindustrian dan Perdagangan Kabupaten Sumedang untuk mendapatkan Surat Izin Usaha dan Perdagangan (SIUP). Setelah melalui beberapa tahapan tersebut maka XY telah memiliki legalitas untuk melakukan usaha Produksi tahu jika dilihat dari lokasi usahanya.

Aspek Sosial, Ekonomi, Budaya dan Lingkungan

Analisis terhadap aspek sosialekonomi-budaya dilakukan untuk menganalisis keberadaan unit usaha produksi tahu XY dari sisi pemerintah dan masyarakat sekitar. Unit usaha produksi tahu $\mathrm{XY}$ dapat berpengaruh secara positif maupun negatif terhadap faktor sosial-ekonomibudaya. Jika dilihat dari sisi ekonomi, keberadaan unit usaha Tahu XY memberikan kontribusi positif terhadap pemerintah yaitu dengan adanya pembayaran pajak kepada pemerintah.

Berdasarkan hasil observasi, dan wawancara dengan warga, keberadaan unit usaha produksi tahu XY memberikan pengaruh positif bagi masyarakat dan lingkungan sekitar. Pada awal pendirian usaha tahu XY, respon dari masyarakat sekitar adalah negatif tetapi, karena pemilik memberikan santunan rutin dan zakat setiap tahunnya kepada masyarakat sekitar sebagai wujud social responsibility Tahu XY maka lambat laun masyarakat mulai menerima keberadaan usaha produksi tahu Sumedang $\mathrm{XY}$.

Dampak yang terjadi terhadap lingkungan dari adanya usaha pabrik tahu XY adalah adanya polusi air yang berasal dari limbah cair yang dihasilkan oleh produksi 
tahu yang dapat menimbulkan bau tidak sedap di sekitar pabrik. Limbah tersebut langsung keluar ke aliran sungai dan langsung dibuang. Pabrik Tahu XY telah menangani dampak polusi air yang terjadi akibat usaha produksi yang dijalankan dengan mensosialisasikan bahwa polusi limbah cair tersebut tidak berbahaya dan tidak terlalu banyak mencemari lingkungan.

Dilihat dari hasil observasi analisis lingkungan, dengan adanya penanganan atas polusi limbah yang ditimbulkan dari usaha tahu XY telah menangani dampak lingkungan yang ditimbulkan terhadap masyarakat sekitar sehingga dapat dikatakan bahwa unit usaha produksi tahu XY layak untuk dijalankan.

\section{Analisis aspek Finansial}

Analisis Finansial

Perhitungan analisis finansial unit usaha produksi tahu XY pada kondisi saat ini (tanpa perubahan) menggunakan kriteria NPV, Net B/C, IRR dan PP. Kriteria kelayakan dari unit usaha produksi ini adalah apabila nilai NPV yang diperoleh selama umur usaha lebih besar dari nol (NPV>0), IRR yang diperoleh lebih besar dari discountrate (IRR $\geq 0$ ), Net $B / C$ lebih besar atau sama dengan satu (Net $\mathrm{B} / \mathrm{C} \geq 1$ ) dan PP lebih kecil dari umur usaha ( $\mathrm{PP}<10$ tahun) maka usaha pembibitan ini dikatakan layak untuk dijalankan. Berdasarkan perhitungan kriteria investasi yang dilakukan dengan umur usaha 10 tahun, maka didapatkan hasil sebagai berikut (Tabel 1).

Tabel 1. Hasil Analisis Finansial pada Kondisi Sekarang (tanpa perubahan)

\begin{tabular}{llll}
\hline No & $\begin{array}{l}\text { Kriteria } \\
\text { Analisis }\end{array}$ & Hasil Analisis & Keterangan \\
\hline 1 & NVP & 579.177 .261 & Layak \\
2 & IRR & 0,41 & Layak \\
3 & Net B/C & 2,92 & Layak \\
4 & PP & 2,63 & Layak \\
\hline
\end{tabular}

Analisis finansial ini dilakukan dengan menggunakan kriteria-kriteria penilaian investasi yaitu Net Present Value (NPV),
Internal Rate of Return (IRR), Net Benefit-Cost Ratio (Net B/C) dan Payback Period (PP).

\section{a) Net Present Value (NPV)}

Hasil analisis finansial menunjukkan nilai NPV usaha produksi tahu XY ini lebih dari nol yaitu Rp. 579.177.261,-. Hal ini menunjukkan dari usaha ini memberikan manfaat bersih sebesar Rp. 579.177.261,selama kurun waktu 10 tahun. Karena nilai NPV yang diperoleh bernilai positif $(>0)$ maka proyek ini layak untuk di jalankan atau dioperasikan.

b) Internal Rate of Return (IRR)

Hasil analisis finansial menunjukkan nilai IRR usaha produksi tahu XY diperoleh yaitu sebesar 0,41\% dimana IRR tersebut lebih dari 0 . Hal ini menunjukkan tingkat pengembalian dari modal yang diinvetasikan adalah sebesar $0,41 \%$ dan proyek ini layak untuk dioperasikan karena memiliki keuntungan dimana IRR lebih besar dari 0 .

\section{c) Net Benefit-Cost Ratio (Net B/C)}

Hasil analisis finansial menunjukkan nilai NET B/C usaha produksi tahu XY yaitu sebesar 2,92. Hal ini menunjukkan setiap Rp. 1 yang dikeluarkan untuk menjalankan proyek maka akan menghasilkan manfaat bersih sebesar Rp. 2,92,-. Hal ini juga menujukkan nilai NET B/C yang dihasilkan lebih dari 1 maka proyek ini layak untuk dijalankan.

\section{d) Payback Period (PP)}

Hasil analisis finansial menunjukkan nilai PP usaha produksi tahu XY yaitu selama 2,63 tahun. Hal ini menunjukkan bahwa proyek usaha dapat mengembalikan modal sebelum umur proyek berakhir dan hal ini juga menyatakan proyek layak untuk dioperasikan.

\section{Analisis Laba Rugi}

Hasil proyeksi laba rugi pada kondisi sekarang tanpa perubahan menunjukkan bahwa unit usaha total keuntungan bersih (EAT) yang diperoleh dari unit usaha produksi tahu XY dalah sebesar Rp. 125.029.500. Keuntungan tersebut diperoleh ditahun kedua setelah memperhitungkan jumlah penerimaan ditahun kedua dikurangi jumlah pengeluaran di awal dan ditahun 
kedua yang diperoleh. Dapat dilihat pada tabel berikut (Tabel 2).

Tabel 2. Analisis laba rugi

\begin{tabular}{|c|c|c|c|c|c|c|}
\hline $\begin{array}{l}\text { Uraian/ } \\
\text { Thn } \\
\end{array}$ & 1 & 2 & 3 & 4 & 5 & 6 \\
\hline \multicolumn{7}{|c|}{ Penerimaan } \\
\hline Penjualan & 1.377 .672 .000 & 1.377 .672 .000 & 1.377 .672 .000 & 1.377 .672 .000 & 1.377 .672 .000 & 1.377 .672 .000 \\
\hline Nilai Sisa & 30.087 .500 & 30.087 .500 & 30.087 .500 & 30.087 .500 & 30.087 .500 & 30.087 .500 \\
\hline Sub Total & 1.407 .759 .500 & 1.407 .759 .500 & 1.407 .759 .500 & 1.407 .759 .500 & 1.407 .759 .500 & 1.407 .759 .500 \\
\hline \multicolumn{7}{|l|}{ Pengeluaran } \\
\hline $\begin{array}{l}\text { Biaya } \\
\text { investasi }\end{array}$ & 300.875 .000 & 0 & 0 & 0 & 0 & 0 \\
\hline $\begin{array}{l}\text { Biaya } \\
\text { operasio- } \\
\text { nal }\end{array}$ & 196.260 .000 & 196.260 .000 & 196.260 .000 & 196.260 .000 & 196.260 .000 & 196.260 .000 \\
\hline $\begin{array}{l}\text { Biaya } \\
\text { Bahan } \\
\text { baku }\end{array}$ & 1.058 .820 .000 & 1.058 .820 .000 & 1.058 .820 .000 & 1.058 .820 .000 & 1.058 .820 .000 & 1.058 .820 .000 \\
\hline Pajak & 27.650 .000 & 27.650 .000 & 27.650 .000 & 27.650 .000 & 27.650 .000 & 27.650 .000 \\
\hline Sub Total & 1.583 .605 .000 & 1.282 .730 .000 & 1.282 .730 .000 & 1.282 .730 .000 & 1.282 .730 .000 & 1.282 .730 .000 \\
\hline $\begin{array}{l}\text { Laba } \\
\text { Bersih }\end{array}$ & (175.845.500) & 125.029 .500 & 250.059 .000 & 375.088 .500 & 500.118 .000 & 625.147 .500 \\
\hline
\end{tabular}

\section{Analisis Sesitivitas}

Analisis sensitivitas dilakukan dengan tujuan untuk melihat apakah akan terjadi perubahan dengan hasil proyek jika adanya suatu kesalahan atau perubahan dalam dasar biaya atau benefit. Variable yang digunakan untuk analisis sensitivitas pada penelitian ini meliputi harga jual turun $10 \%$, kenaikkan harga bahan baku dan bahan tambahan sebesar 20\% dan kenaikkan biaya operasional/produksi sebesar 15\%. Hasil analisis dapat dilihat pada (Tabel 3) harga jual turun 10\%, tabel biaya bahan baku dan bahan tambahan naik $20 \%$ dan biaya operasional naik 15\%.

Hasil analisis sensitivitas (Tabel 3), diketahui usaha ini saat dilakukan penurunan harga jual sebesar $10 \%$ usaha ini tidak layak dilaksanakan dimana usaha ini memili nilai NPV sebesar Rp. (267.342.545),-. IRR yang dihasilkan yaitu sebesar $-0,04 \%$ dimana IRR lebih besar dari nol, Net B/C yang dihasilkan lebih besar dari satu yaitu 0,11 dengan demikian penurunan harga jual sebesar 10\% tidak layak dikembangkan dan mengaruh terhadap harga jual tahu jika dinaikan sebesar $10 \%$. Hasil analisis payback periode nilai pengembalian investasi usaha dapat dikembalikan dalam waktu -27,32 tahun.

Tabel 3. Analisis Sensitivitas Harga Jual Turun $10 \%$

\begin{tabular}{|c|c|c|c|}
\hline No & $\begin{array}{l}\text { Kriteria } \\
\text { analisis }\end{array}$ & Hasil analisis & Keterangan \\
\hline 1 & NPV & 267.342 .545 & $\begin{array}{l}\text { Tidak } \\
\text { Layak }\end{array}$ \\
\hline 2 & NET B/C & 0,11 & $\begin{array}{l}\text { Tidak } \\
\text { Layak }\end{array}$ \\
\hline 3 & IRR & $-0,04 \%$ & $\begin{array}{l}\text { Tidak } \\
\text { Layak }\end{array}$ \\
\hline 4 & PP & $-27,32$ & $\begin{array}{l}\text { Tidak } \\
\text { Layak }\end{array}$ \\
\hline
\end{tabular}

Hasil analisis sensitivitas (Tabel 4), dapat diketahui usaha ini saat dilakukan kenaikan bahan baku dan bahan tambahan sebesar 20\% usaha ini layak dilaksanakan dimana usaha ini memili nilai NPV sebesar Rp. 39.254.149-. IRR yang dihasilkan yaitu sebesar 0,12\% dimana IRR lebih besar dari 0, 
Net B/C yang dihasilkan lebih kecil dari satu yaitu 1,13 dengan demikian kenaikan bahan baku sebesar 20\% layak dikembangkan. Hasil analisis payback periode nilai pengembalian investasi usaha dapat dikembalikan dalam waktu 8,76 tahun, layak karena lebih dari 10 tahun.

Tabel 4. Analisis Sensitivitas Biaya Bahan Baku dan Bahan Tambahan Naik $20 \%$

\begin{tabular}{llll}
\hline No & $\begin{array}{l}\text { Kriteria } \\
\text { analisis }\end{array}$ & $\begin{array}{l}\text { Hasil } \\
\text { analisis }\end{array}$ & Keterangan \\
\hline 1 & NPV & 39.254 .149 & Layak \\
2 & NET B/C & 1,13 & Layak \\
3 & IRR & $0,12 \%$ & Layak \\
4 & PP & 8,76 & Layak \\
\hline
\end{tabular}

Hasil analisis sensitivitas (Tabel 5), diketahui usaha ini saat dilakukan kenaikan biaya operasi produksi 15\% usaha ini layak dilaksanakan dimana usaha ini memili nilai NPV sebesar Rp. 391.651.217,-. IRR yang dihasilkan yaitu sebesar $0,31 \%$ dimana IRR lebih besar dari 0 , Net B/C yang dihasilkan lebih besar dari satu yaitu 2,30 dengan demikian kenaikan biaya operasional sebesar 20\% layak dikembangkan. Dari hasil analisis payback periode nilai pengembalian investasi usaha dapat dikembalikan dalam waktu 3,48 tahun.

Tabel 5. Analisis Sensitivitas Biaya Operasional Naik 15\%

\begin{tabular}{llll}
\hline No & $\begin{array}{l}\text { Kriteria } \\
\text { analisis }\end{array}$ & $\begin{array}{l}\text { Hasil } \\
\text { analisis }\end{array}$ & Keterangan \\
\hline 1 & NPV & 391.651 .217 & Layak \\
2 & NET B/C & 2,30 & Layak \\
3 & IRR & $0,31 \%$ & Layak \\
4 & PP & 3,48 & Layak \\
\hline
\end{tabular}

\section{KESIMPULAN}

Berdasarkan hasil penelitian dan pembahasan maka dapat disimpulkan bahwa model usaha produksi tahu XY adalah jenis usaha yang layak untuk dijalankan khususnya pada produksi makanan tradisional khas Sumedang untuk memenuhi kebutuhan masyarakat yang lebih mencintai makanan tradisional tersebut.

Berdasarkan hasil analisis finansial menunjukkan usaha ini layak untuk dilaksanakan atau dijalankan. Model usaha produksi tahu XY memiliki nilai NPV selama kurun waktu 10 tahun adalah sebesar Rp. 579.177.261,-. Dengan kapasitas produksi per bulan menghasilkan tahu sebanyak 216.000 biji, ampas tahu sebanyak $6.806 \mathrm{~kg}$ per bulan. Nilai IRR yang diperoleh yaitu sebesar $0,41 \%$ dimana IRR tersebut lebih besar 0 . Net B/C yang diperoleh adalah sebesar 2,92. Hal ini berarti, setiap Rp 1 biaya yang dikeluarkan untuk menjalankan usaha ini akan mnghasilkan manfaat bersih sebesar Rp. 2,92. Payback Period yang diperoleh adalah 2,63 tahun. Analisis sensitivitas untuk proyek ini menunjukkan kenaikkan biaya operasional atau produksi sebesar 15\%, kenaikkan bahan baku dan bahan tambahan sebesar 20\% tidak berpengaruh terhadap usaha ini.

Analisis sensitivitas pada penurunan harga jual sebesar $10 \%$, pada hasil analisis ini, menunjukan bahwa usaha ini tidak layak untuk dijalankan karena mempengaruhi harga jual produksi tahu dan mendapakan angka analisis negatif.

\section{DAFTAR PUSTAKA}

Dewi. 2016. Analisis Pengembangan Usaha Tahu. Jurnal Agribisnis. 11(18): 189-192.

Bakhtiar A, Ibrahim JT, Relawati R. 2018. Analisis Kelayakan Finansial Agroindustri Tahu. RDS. Jurnal Agribest. 2 (2): 174-178.

Hapsari CM, Yusuf S, Nurdiana. A. 2016. Analisis Kelayakan Usaha Pengasapan Ikan Di Desa Toolawawo Kecamatan Lalonggasumeeto Kabupaten Konawe. Jurnal Sosial Ekonomi Perikanan FPIK UHO. 1(2): 85-97.

Husnan S dan Suwarsono M. 2014. Studi Kelayakan Proyek Bisnis. Yogyakarta: UPP STIM YKPN.

Iskandar W, Yuniar, Iskandar A. 2015. Analisis Kelayakan Usaha STEAK CAFE Di Kota Pekanbaru. Jurnal reka integra. 1(3): 353-364.

Kurniawan A. 2016. Analisis Kelayakan Usaha Tahu Gemilang di Karawang. Program 
Studi Teknik Industri, Institut Teknologi Nasional Malang.

Maharani TD. 2017. Proses Pembuatan Produk Tahu di UD. Sumber Jaya Kenjeran Surabaya. Skripsi. Fakultas Teknologi Pertanian.

Mansyur M, Ma'ruf A, Ashadi RW. 2015. Studi kelayakan usaha penyulingan minyak serai wangi (Citronella oli) di Lembang Bandung. Jurnal Pertanian . 6(1): 15-19.

Syarif. 2014. Sistem Operasional dan Usaha Produksi. Jurnal Analisis Sensitivitas. Fakultas Manajemen Industri. Universitas Padjajaran Bandung.

Simanjuntak PM. 2017. Analisis Kelayakan Finansial Pada Perusahaan Tahu. Jurnal Neonatus. 7(2): 84-93. 